Article

\title{
Ni-Based Catalyst Derived from NiAl Layered Double Hydroxide for Vapor Phase Catalytic Exchange between Hydrogen and Water
}

\author{
Xiaoyu $\mathrm{Hu}^{1,2,+}$, Peilong $\mathrm{Li}^{2,+}{ }^{\dagger}$, Xin Zhang ${ }^{2}$, Bin $\mathrm{Yu}^{2}$, Chao Lv ${ }^{2}$, Ning Zeng ${ }^{2}$, Junhong Luo ${ }^{2}$, \\ Zhi Zhang ${ }^{2}$, Jiangfeng Song ${ }^{2, *}$ (i) and Yong Liu ${ }^{1, *}$ \\ 1 School of Resource Environmental and Safety Engineering, University of South China, \\ Hengyang 421001, China; hu822066398@163.com \\ 2 Institute of Materials, China Academy of Engineering Physics, Jiangyou 621908, China; \\ lipeilong2012@126.com (P.L.); a753951_xin@163.com (X.Z.); yubincaep@163.com (B.Y.); \\ lvchao219@foxmail.com (C.L.); 15882895785@139.com (N.Z.); luojunhong@caep.cn (J.L.); \\ zhangzhi@caep.cn (Z.Z.) \\ * Correspondence: iterchina@163.com (J.S.); dtscichina@126.com (Y.L.); Tel.: +86-139-9010-5175 (J.S.); \\ +86-135-0734-1111 (Y.L.) \\ + These authors contributed equally to this work.
}

Received: 17 October 2019; Accepted: 22 November 2019; Published: 25 November 2019

\begin{abstract}
A high-efficient and low-cost catalyst on hydrogen isotope separation between hydrogen and water is an essential factor in industrial application for heavy water production and water detritiation. In past studies, Pt-based catalysts were developed but not practical for commercial use due to their high cost for vapor phase catalytic exchange (VPCE), while for impregnated nickel catalysts with a lower cost the problems of agglomeration and low Ni utilization existed. Therefore, to solve these problems, in-situ grown Ni-based catalysts (NiAl-LDO) derived from a layered double hydroxide (LDH) precursor were fabricated and first applied in VPCE in this work. Compared with traditional impregnated Ni-based catalysts, NiAl-LDO catalysts own a unique layered structure, homogeneous dispersed metallic phase, higher specific surface area as well as stronger metal-support interactions to prevent active metal from agglomerating. These advantages are beneficial for exposing more active sites to improve dynamic contacts between $\mathrm{H}_{2}$ and $\mathrm{HDO}$ in a catalyst surface and can bring excellent catalytic activity under a reaction temperature of lower than $400{ }^{\circ} \mathrm{C}$. Additionally, we found that the dissociative chemisorption of $\mathrm{HDO}$ and $\mathrm{H}_{2}$ occurs not only in $\mathrm{Ni}$ (111) but also in $\mathrm{NiO}$ species where chemisorbed $\mathrm{H}(\mathrm{ads}), \mathrm{D}(\mathrm{ads}), \mathrm{OH}(\mathrm{ads})$ and $\mathrm{OD}(\mathrm{ads})$ are formed. The results highlight that both of the $\mathrm{Ni}^{2+}$ species and $\mathrm{Ni}^{0}$ species possess catalytic activities for VPCE process.
\end{abstract}

Keywords: vapor phase catalytic exchange; layered double oxides; Ni catalyst; water detritiation

\section{Introduction}

Tritium plays a pivotal role in nuclear power plants, nuclear fuel reprocessing, as well as future fusion reactors [1,2]. However, tritiated water damages the human body and environment seriously due to its radioactivity and toxicity. Thus, stringent environment standards for the development of inland nuclear power were established, like in China. Besides, the treatment of tritiated water possesses a great significance in nuclear energy and environment [3,4]. Hydrogen isotope exchange is an important process for tritium extraction from heavy water and detritiation of tritium-containing sewage [5-7]. Particularly, the vapor phase catalytic exchange (VPCE) reaction, which processes the tritium, is transferred from vaporous water into gaseous hydrogen $\left(\mathrm{HTO}_{\text {vapor }}+\mathrm{H}_{2 \text { gas }} \rightleftharpoons \mathrm{HT}_{\text {gas }}+\right.$ $\mathrm{H}_{2} \mathrm{O}_{\text {gas }}$ ) and has attracted attention due to its nontoxicity, non-corrosiveness, simple craft as well 
as a high separation factor throughout the hydrogen isotope exchange reaction. Hence is owes a huge potential for industrial application [8-13]. In VPCE, the availability of active sites (transport of gaseous hydrogen and vaporous water to a catalyst surface as well as the dissociative chemisorption) is key for the hydrogen isotope exchange reaction. To achieve a highly efficient catalytic exchange reaction, some strategies have been developed such as enhancing the dispersion and utilization of active metals (Ni, Cr, Pd, Pt, Rh, Ru etc.), using high specific surface area supports as well as the cooperation of multiple metals $[10,12,14]$. Meanwhile, a mass of hydrophobic catalysts have been fabricated including $\mathrm{Pt} / \mathrm{C}, \mathrm{Pt}-\mathrm{Ir} / \mathrm{C}, \mathrm{Pt}-\mathrm{Fe} / \mathrm{C}, \mathrm{Pt}-\mathrm{Ni} / \mathrm{C}[10,11,13,15]$. The impregnated $\mathrm{Pt} / \mathrm{Al}_{2} \mathrm{O}_{3}$ and $\mathrm{Ni} / \mathrm{Al}_{2} \mathrm{O}_{3}$ [16-18] are two kinds of widely researched catalysts for $\mathrm{VPCE} . \mathrm{Pt} / \mathrm{Al}_{2} \mathrm{O}_{3}$ catalysts have excellent activity, but their extravagant cost is not profitable for commercial application. Traditional impregnated $\mathrm{Ni} / \mathrm{Al}_{2} \mathrm{O}_{3}$ catalysts are not able to be used efficiently due to the inevitable aggregation of active metal after calcination and reduction. Accordingly, it is highly desirable to develop low-cost catalysts, like Ni-based catalysts, to realize high catalytic performance for VPCE. The substitutes of Pt-based catalysts are due to their similar property for dissociative chemisorption of reactants on the Ni-based catalysts' surface. Unfortunately, most Ni-based catalysts were prepared by impregnating metal precursors on supports, followed by calcining and reducing, resulting in the unexpected uncontrollable aggregation of metal species and inefficient availability of active metal. For instance, Zhang et al. prepared $\mathrm{Al}_{2} \mathrm{O}_{3}$ supported by Ni catalysts using the impregnation method, but extra $\mathrm{Ni}$ loading caused serious $\mathrm{Ni}$ aggregation, blocking active sites and leading to poor $\mathrm{CO}_{2}$ methanation performance [19]. To improve metal dispersion and catalytic performances, some researchers prepared in-situ catalysts for hydrodechlorination [20] and methane decomposition [21]. Therefore, it is very significant to explore an in-situ grown Ni catalyst with an outstanding dispersion to prevent active metal from aggregating in supports for VPCE process.

Layered double hydroxide (LDH), also known as hydrotalcite-like materials or anionic clays, are a significant class of layered-structure materials with a chemical composition expressed by the general formula $\left[\mathrm{M}_{1-\mathrm{x}}^{2+} \mathrm{M}_{\mathrm{x}}^{3+}(\mathrm{OH})_{2}\right]^{\mathrm{x}+}\left[\mathrm{A}_{\mathrm{x} / \mathrm{n}}^{\mathrm{n}-} \cdot \mathrm{yH}_{2} \mathrm{O}\right]^{\mathrm{x}-}$ where $\mathrm{M}^{2+}$ and $\mathrm{M}^{3+}$ are di- and trivalent metal cations, respectively, and $\mathrm{A}^{\mathrm{n}-}$ denotes an organic or inorganic anion with a n-valent anion. The unique supramolecular structure with a uniform dispersion for $\mathrm{M}^{2+}$ and $\mathrm{M}^{3+}$ ions within the layers is from precise control of both the inorganic layers and the interlayer gallery anions of LDH without the formation of "lakes" cations [22]. The adjustability of the hydrotalcite structure gives it uniquely adjustable properties, which are further applicable in numerous areas. Various literature reported the wide applications of LDH as catalyst precursors, catalyst supports, adsorbents and ion exchangers in different research directions, e.g., gas removing, selective hydrogenation, electro-catalysis oxidation etc. [23-25]. Especially, when using LDH as catalyst precursors, the LDH-derived catalyst could maintain a layer structure and keep a highly dispersed metallic phase [26]. Importantly, some active metal (Ni, Cr, Pd, Pt etc.) for hydrogen isotope exchange processes could be easily introduced into the LDH by using a hydrothermal method and co-precipitation, ion-exchange, precipitation-reduction method [23]. These advantages of LDH inspire us to fabricate an efficient VPCE catalyst from LDH.

In this work, we report the effective in-situ growth of NiAl layered double oxides (LDO) derived from the LDH precursor which are firstly applied for the VPCE process. The layered structure, high specific surface area, porous structure, homogeneous metallic phase as well as stronger metal-support interactions of in-situ Ni catalysts contribute to the much higher VPCE activity in comparison with the impregnated $\mathrm{NiO} / \gamma-\mathrm{Al}_{2} \mathrm{O}_{3}$ catalysts at a reaction temperature of below $400{ }^{\circ} \mathrm{C}$. Importantly, the catalytic exchange mechanism of transition-metal Ni for VPCE is also discussed, both $\mathrm{Ni}^{0}$ species and $\mathrm{NiO}$ species can conduce hydrogen isotope exchange processes between hydrogen and water. 


\section{Experimental}

\subsection{Material}

Nickel nitrate hexahydrate $\left(\mathrm{Ni}\left(\mathrm{NO}_{3}\right)_{2} \cdot 6 \mathrm{H}_{2} \mathrm{O}, 98 \%\right)$, aluminum nitrate nonahydrate $\left(\mathrm{Al}\left(\mathrm{NO}_{3}\right)_{3} \cdot 9 \mathrm{H}_{2} \mathrm{O}, 98 \%\right)$ and urea $\left(\left(\mathrm{NH}_{2}\right)_{2} \mathrm{CO}, 98 \%\right)$ were obtained from Aladdin Chemical Reagent Co. Ltd. (Shanghai, China). Activated alumina was purchased from Macklin Chemical Reagent Co. Ltd. (Shanghai, China). All chemicals were analytical grade and used without further purification. The used ultrapure water throughout the experimental processes was obtained from a Milli-Q ultrapure system $(10.5 \mathrm{M} \Omega \mathrm{cm})$.

\subsection{Synthesis of Petal-Like NiAl-LDH}

The NiAl-LDH was synthesized by the conventional urea hydrolysis method $[25,27,28]$. In a typical procedure, as illustrated in Scheme $1 \mathrm{~A}, \mathrm{Ni}\left(\mathrm{NO}_{3}\right)_{2} \cdot 6 \mathrm{H}_{2} \mathrm{O}(0.012 \mathrm{~mol})$ and $\mathrm{Al}\left(\mathrm{NO}_{3}\right)_{3} \cdot 9 \mathrm{H}_{2} \mathrm{O}(0.006 \mathrm{~mol})$ as well as urea $(0.084 \mathrm{~mol})$ with a $\mathrm{Ni} / \mathrm{Al} /$ urea molar ratio of 2/1/14 were dissolved in $320 \mathrm{~mL}$ ultrapure water to form a mixed solution with vigorous stirring. Subsequently, the homogeneous and transparent solution was transferred into $500 \mathrm{~mL}$ Teflon-lined stainless-steel autoclave, sealed and heated with oven at $150{ }^{\circ} \mathrm{C}$ for $12 \mathrm{~h}$. After cooling the autoclave to $25^{\circ} \mathrm{C}$, the precipitate was collected and thoroughly washed by ultrapure water several times, followed by drying at $70^{\circ} \mathrm{C}$ overnight in an oven to get NiAl-LDH.

A

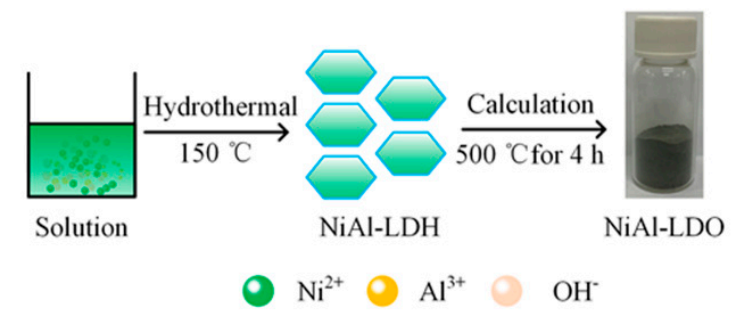

B

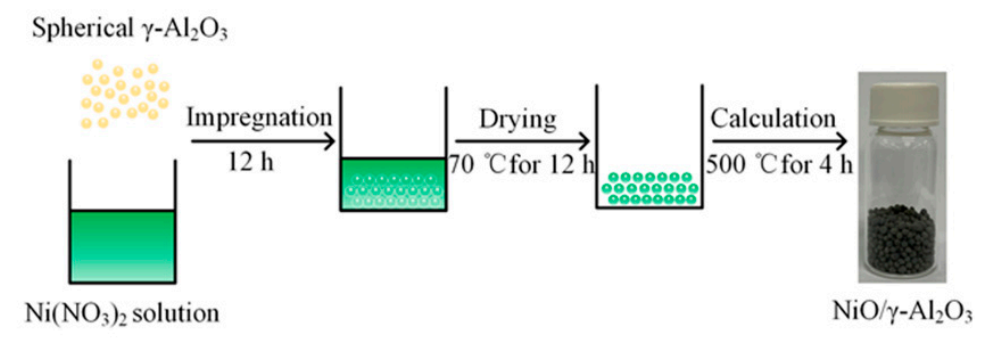

Scheme 1. Illustrations of the materials preparations of (A) NiAl-LDH and NiAl-LDO; (B) $\mathrm{NiO} / \gamma-\mathrm{Al}_{2} \mathrm{O}_{3}$.

\subsection{Preparation of Spherical $\mathrm{Ni}\left(\mathrm{NO}_{3}\right)_{2} / \gamma-\mathrm{Al}_{2} \mathrm{O}_{3}$}

$\mathrm{Ni}\left(\mathrm{NO}_{3}\right)_{2} / \gamma-\mathrm{Al}_{2} \mathrm{O}_{3}$ was prepared by a traditional impregnation method [20]. Typically, as illustrated in Scheme $1 \mathrm{~B}, 10 \mathrm{~g} \gamma-\mathrm{Al}_{2} \mathrm{O}_{3}$ was placed in a beaker loaded with $12.5 \mathrm{~mL} 3 \mathrm{~mol} \mathrm{~L}-1 \mathrm{Ni}^{-}\left(\mathrm{NO}_{3}\right)_{2}$ water solution and then impregnated for $12 \mathrm{~h}$ at room temperature, followed by drying at $70{ }^{\circ} \mathrm{C}$ for $12 \mathrm{~h}$. The products were named $\mathrm{Ni}\left(\mathrm{NO}_{3}\right)_{2} / \gamma-\mathrm{Al}_{2} \mathrm{O}_{3}$ and collected in the bottle to wait for further treating.

\subsection{Preparations of $\mathrm{NiAl}-\mathrm{LDO}$ and $\mathrm{NiO} / \gamma-\mathrm{Al}_{2} \mathrm{O}_{3}$}

The precursors NiAl-LDH and $\mathrm{Ni}\left(\mathrm{NO}_{3}\right)_{2} / \gamma-\mathrm{Al}_{2} \mathrm{O}_{3}$ were calcinated at $500{ }^{\circ} \mathrm{C}$ for $4 \mathrm{~h}$ with a heating rate of $5{ }^{\circ} \mathrm{C} \mathrm{min}-1$ in air. After slowly cooling to $25^{\circ} \mathrm{C}$, the products were named as NiAl-LDO and $\mathrm{NiO} / \gamma-\mathrm{Al}_{2} \mathrm{O}_{3}$, respectively. 


\subsection{Characterization}

Powder X-ray diffraction (XRD) patterns were recorded using a DX-2700 X-ray powder diffractometer (Haoyuan Inc., Liaoning, China) with a $\mathrm{Cu}$ Ka radiation source $(\lambda=1.54059 \AA)$ in 2 range between $5^{\circ}$ and $80^{\circ}$, step size $0.05^{\circ}$, and operated at a voltage of $40 \mathrm{kV}$ and a current of $30 \mathrm{~mA}$. Inductively coupled plasma optical emission spectrometer (ICP-OES) (Agilent, 725ES) (Palo Alto, CA, USA) was applied to identify the elemental content of $\mathrm{Ni}$ and $\mathrm{Al}$. The morphologies of samples were performed using a scanning electron microscope (SEM, FEI Quanta 650) (Hillsboro, OR, USA). The specimen positioned on a mesh grid was examined using transmission electron microscopy coupled to the energy-dispersive X-ray spectroscopy (TEM, FEI Talos F200S) (Hillsboro, OR, USA) at a voltage of $200 \mathrm{kV}$. Selected area electron diffraction (SAED) was performed in TEM (FEI Talos F200S) and TEM with energy dispersive $\mathrm{X}$-ray spectroscopy mapping (TEM EDS maps) (FEI Talos F200S) was also required to recognize the distributions of $\mathrm{Ni}, \mathrm{Al}, \mathrm{C}$ and $\mathrm{O}$ for NiAl-LDH and NiAl-LDO. Low-temperature $\mathrm{N}_{2}$ adsorption-desorption experiments were conducted using a Micromeritics ASAP 2469 instrument (Norcross, GA, USA). Specific surface area and average pore diameters were calculated by the Brunauer-Emmett-Teller (BET) method or the Barrett-Joyner-Halenda (BJH) method applied to desorption isotherms. The surface valence states of the prepared samples before and after reaction were analyzed by X-ray photoelectron spectroscopy (XPS) (ESCALAB, 250Xi) (Waltham, MA, USA).

$\mathrm{H}_{2}$ temperature-programmed reduction $\left(\mathrm{H}_{2}\right.$-TPR) of the samples were conducted on a chemical adsorption apparatus (AMI-300) (Bayport, TX, USA) equipped with a thermal conductivity detector (TCD) signal detector. Prior to the $\mathrm{H}_{2}$-TPR experiment, about $0.1000 \mathrm{~g}$ of NiAl-LDH powder (Ni $36.75 \mathrm{wt} . \%, \mathrm{ICP}$ ) was loaded in a quartz reactor and were further pre-treated with continuous $\mathrm{Ar}$ flow at $70{ }^{\circ} \mathrm{C}$ for $30 \mathrm{~min}$, followed by cooling down to $30^{\circ} \mathrm{C}$. Then, the $\mathrm{H}_{2}$-TPR of the NiAl-LDH was performed with a ramp rate of $5^{\circ} \mathrm{C} \mathrm{min}^{-1}$ in a stream of $15 \mathrm{cc} \mathrm{min}{ }^{-1} 10 \% \mathrm{H}_{2}$ in Ar from $30^{\circ} \mathrm{C}$ to $1000{ }^{\circ} \mathrm{C}$. To analyze the amount of hydrogen uptake for NiAl-LDH, the corresponding pulse tests also were carried out during the $\mathrm{H}_{2}$-TPR process. The outlet gas was connected with a drying bed filling with molecular sieve to absorb the moisture generated during the reduction process. $\mathrm{H}_{2}-\mathrm{TPR}$ experiments of $\mathrm{NiAl}-\mathrm{LDO}$ and $\mathrm{NiO} / \gamma-\mathrm{Al}_{2} \mathrm{O}_{3}$ were carried out with a similar process under the same amount of $\mathrm{Ni}$ content. For NiAl-LDO, about $0.1000 \mathrm{~g}$ of NiAl-LDH was loaded in a quartz reactor and then the precondition was changed to $500{ }^{\circ} \mathrm{C}$ for $4 \mathrm{~h}$ with continuous Ar flow to obtain NiAl-LDO. Furthermore, to ensure same amount of $\mathrm{Ni}$ content with $\mathrm{NiAl}-\mathrm{LDH}, 0.2317 \mathrm{~g}$ of $\mathrm{NiO} / \gamma-\mathrm{Al}_{2} \mathrm{O}_{3}(\mathrm{Ni} 15.87 \mathrm{wt} . \%$, ICP) was used for carrying out $\mathrm{H}_{2}$-TPR experiments and test conditions were the same as with NiAl-LDH. The $\mathrm{H}_{2}$ consumption signal of each sample in the whole $\mathrm{H}_{2}$-TPR process was monitored by a TCD detector, while $\mathrm{H}_{2}$ uptake was calculated using the following simplified equations.

Calibration Value:

$$
C V=V_{\mathrm{s} 1} W_{\mathrm{H}_{2}} / S_{\mathrm{pa}}
$$

Volume:

$$
V=C V \times S_{\mathrm{Sa}}
$$

Total volume adsorbed:

$$
Q_{\mathrm{tc}}=P V /(R(T+273.15))
$$

Sample $\mathrm{H}_{2}$ consumption:

$$
Q_{\mathrm{sc}}=Q_{\mathrm{tc}} / m
$$

where $V_{\mathrm{s} 1}$ is the loop volume of the sample cell $(\mu \mathrm{L}), W_{\mathrm{H} 2}$ is percentage of analytical gas $\left(\mathrm{H}_{2}, 10 \%\right), S_{\mathrm{pa}}$ is the mean calibration pulse area, $C V$ is the calibration value, $V$ is the volume $(\mu \mathrm{L}), S_{\text {sa }}$ is the analytical area signals of TCD, $Q_{\mathrm{tc}}$ is the total volume adsorbed $(\mu \mathrm{mol}), P$ is the analytical pressure $(\mathrm{atm}), R$ is the standard coefficient $(0.08206), T$ is the loop temperature $\left({ }^{\circ} \mathrm{C}\right), m$ is the weight of sample $(\mathrm{g})$, and $Q_{\mathrm{sc}}$ is $\mathrm{H}_{2}$ the consumption of sample $\left(\mu \mathrm{mol} \mathrm{g}{ }^{-1}\right)$. 


\subsection{Catalytic Activity Evaluation}

Catalytic performance tests of the catalysts were performed in a stainless-steel reaction column of internal diameter $8 \mathrm{~mm}$. The superheated mixture of $\mathrm{H}_{2}$ and $\mathrm{HDO}$ (such as $100^{\circ} \mathrm{C}, 150^{\circ} \mathrm{C}, 200^{\circ} \mathrm{C}$, $250{ }^{\circ} \mathrm{C}, 300{ }^{\circ} \mathrm{C}, 400{ }^{\circ} \mathrm{C}$ or $500{ }^{\circ} \mathrm{C}$ ) flowed to the reaction column with the same temperature. About $0.3150 \mathrm{~g}$ of NiAl-LDO (actual Ni $47.11 \mathrm{wt} . \%$, ICP; theoretical one $58.57 \mathrm{wt} . \%$ ) and about $0.9349 \mathrm{~g}$ of $\mathrm{NiO} / \gamma-\mathrm{Al}_{2} \mathrm{O}_{3}$ (actual $\mathrm{Ni} 15.87 \mathrm{wt} . \%$, ICP; theoretical one $17.19 \mathrm{wt} . \%$ ) were used to ensure the same mass of $\mathrm{Ni}(14.84 \mathrm{wt} . \%)$ for the VPCE process, then samples were placed into a reaction column and heated up to reaction temperature in the flow of Ar. The total height of the catalyst layer was $\sim 30-34 \mathrm{~mm}$. The experimental apparatus was as outlined in Figure 1.

The $\mathrm{H}_{2}$ and vaporous $\mathrm{HDO}$ (molar feed ratio of deuterated water/hydrogen = 1, molar fraction of deuterium is $5.62 \%$, molar fraction of hydrogen is $99.999 \%$ ) were fed into the reaction column co-currently from the commingler to the reaction column. The HD concentrations in hydrogen gas at the reaction column outlet were analyzed with an Agilent 7890 gas chromatograph. The dedeuterium factor (DF) was applied for evaluating catalytic activity, defined as the following equation [29]:

$$
D F=x_{\mathrm{t}} / x_{\mathrm{b}}
$$

where $x_{\mathrm{t}}$ is the molar concentration ratio of initial deuterium in water, while $x_{\mathrm{b}}$ is the one in outlet water.

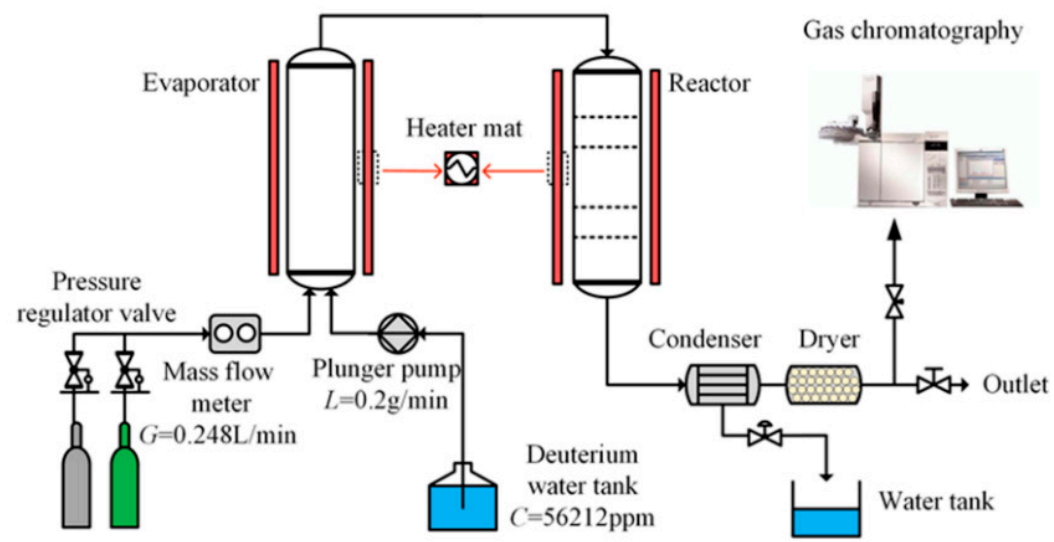

Figure 1. Experimental apparatus for the VPCE process.

\section{Results and Discussion}

\subsection{Material Characterization}

A series of NiAl-LDH were prepared by adjusting synthesis conditions including hydrothermal temperature, crystallization time and $\mathrm{Ni} / \mathrm{Al} /$ urea molar ratio, which were displayed in the Supplementary Materials (Figures S1-S3). The structural characteristics of the NiAl-LDH were evaluated from the XRD data, presented in Table S1. In the powder XRD patterns of NiAl-LDH (treated by only adjusting hydrothermal temperature from $110^{\circ} \mathrm{C}$ to $150^{\circ} \mathrm{C}$ ), a markable increase of (003) integral intensity were observed with increasing hydrothermal temperature, which indicated the rising content of the LDH crystalline phase in the NiAl-LDH. What's more, the full width at half the maxima (FWHM) value of (003) reflections decreased in dependence on hydrothermal temperature, illustrating an increased crystallite size, in a good agreement with the calculated crystallite size (using Scherrer's formula listed in Table S1). The increasing crystallization time also resulted in the increases of (003) integral intensity and LDH crystallite size. However, the influence hydrothermal time on (003) integral intensity became unsharp from $12 \mathrm{~h}$ to $36 \mathrm{~h}$, revealing that the effect of hydrothermal time on samples' crystallinity was limited. In addition, the little effect of the $\mathrm{Ni} / \mathrm{Al} /$ urea molar ratio was discovered with undramatic variation of XRD data (include integral intensity, half-height $\left(\mathrm{W}_{1 / 2}\right)$, crystallite size) due to the similar alkaline environment provided by decomposing urea under a high hydrothermal 
temperature. Kovanda, F. et al. [30] and Chen, H. [31] reported similar changes in crystallinity with different hydrothermal treatments on properties of NiAl-LDH and microstructure control of oriented LDH films. The NiAl-LDH with the higher crystallinity in comparison with other samples were characterized by XRD analysis as shown in Figure 2A. The well-defined main diffraction peaks at $2 \theta=$ $11.7^{\circ}, 23.5^{\circ}, 35.1^{\circ}, 39.7^{\circ}, 47.3^{\circ}, 61.2^{\circ}$ and $62.5^{\circ}$ correspond to the (003), (006), (012), (015), (018), (110),

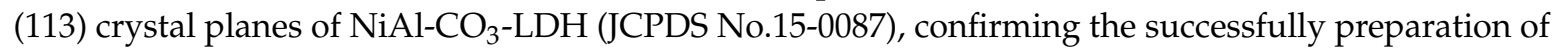
$\mathrm{NiAl}-\mathrm{LDH}$ [32]. After the calcining process, the disappearance of LDH characteristic diffraction peaks and the occurring of diffraction peaks at $37.1^{\circ}, 43.4^{\circ}$ and $63.2^{\circ}$ typical for $\mathrm{NiO}$ (JCPDS NO. 01-1239) indicate the complete conversion of NiAl-LDH to NiAl-LDO [33]. At the same time, the absence of main peaks for $\mathrm{Al}_{2} \mathrm{O}_{3}$ in XRD pattern of NiAl-LDO (Figure 2A) is a demonstration for affirming the amorphous form of $\mathrm{Al}_{2} \mathrm{O}_{3}$ in NiAl-LDH and NiAl-LDO. In addition, as shown in Figure 2B, the XRD pattern of $\mathrm{NiO} / \gamma-\mathrm{Al}_{2} \mathrm{O}_{3}$ demonstrate peaks of $\mathrm{NiO}$ and $\mathrm{Al}_{2} \mathrm{O}_{3}$, indicating the coexistence of $\mathrm{NiO}$ and $\mathrm{Al}_{2} \mathrm{O}_{3}$ phases (JCPDS 10-0425 [34]).

A

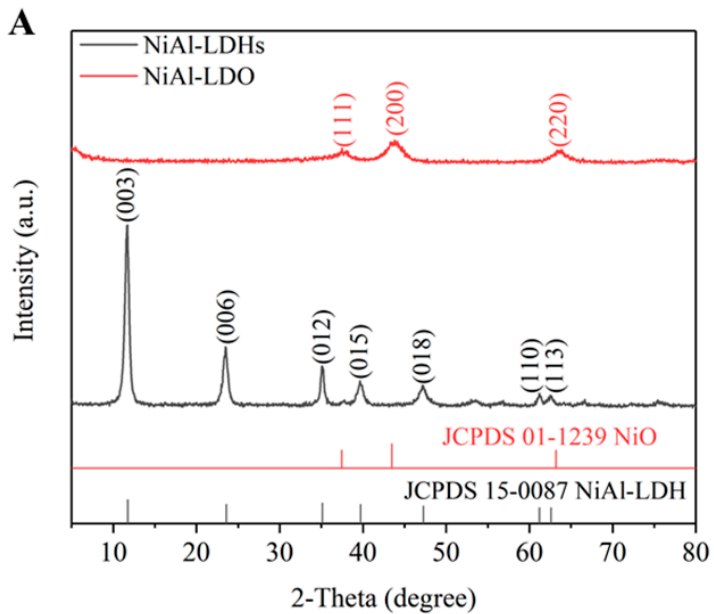

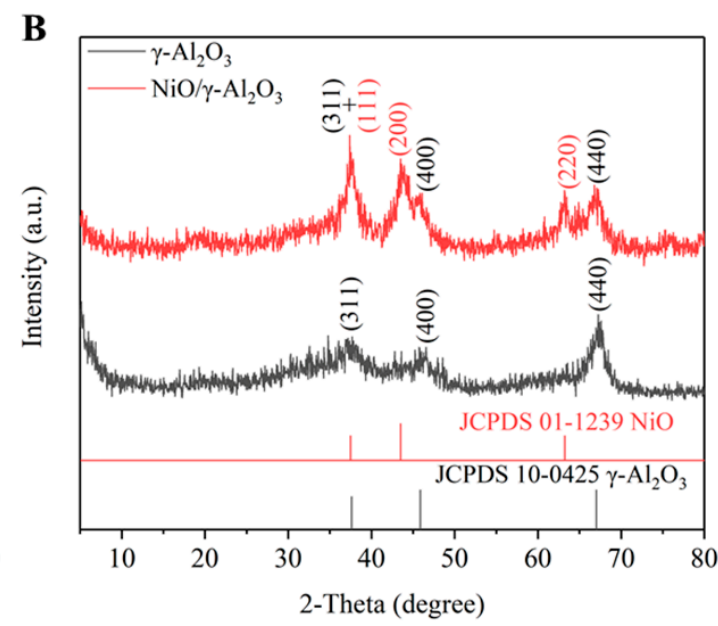

B

Figure 2. XRD patterns of (A) NiAl-LDH and NiAl-LDO; (B) $\gamma-\mathrm{Al}_{2} \mathrm{O}_{3}$ powders and calcinated $\mathrm{NiO} / \gamma-\mathrm{Al}_{2} \mathrm{O}_{3}$ powders grinded from the spherical $\gamma-\mathrm{Al}_{2} \mathrm{O}_{3}$ and the spherical $\mathrm{NiO} / \gamma-\mathrm{Al}_{2} \mathrm{O}_{3}$, respectively.

The morphology and micro-structure information of synthesized samples were investigated by SEM and TEM. As exhibited in Figure 3A, the prepared NiAl-LDH have an interconnected hierarchical structure and interlamellar petal-like nanosheets with a mean thickness of $18.7 \mathrm{~nm}$. Its unique petal-like nanosheet was also reported in former literature [35,36]. Moreover, as shown in Figure 3B, specially superimposed sheets of NiAl-LDH could be observed, in good agreement with the above SEM results. Further EDS mapping of NiAl-LDH confirms the spatial distribution of chemical components (Figure 3B), demonstrating a homogeneous distribution of $\mathrm{Ni}, \mathrm{Al}, \mathrm{C}, \mathrm{O}$ in NiAl-LDH. Inspiringly, even after calcination at $500{ }^{\circ} \mathrm{C}$, the layered structure could maintain in NiAl-LDO (Figure 3C). Additionally, the TEM (Figure 3D) confirms the porous structure, which would promote ion diffusion and catalytic activity. What is more, the EDS mapping of NiAl-LDO shows the homogeneous distribution of $\mathrm{Ni}, \mathrm{Al}$, $\mathrm{C}, \mathrm{O}$, suggesting that the Ni species did not aggregate in the calcination process. The SAED patterns (Figure S4A,B) exhibit well-defined diffraction spots, which are attributed to the (110) planes of the $\mathrm{LDH}$ and the (220) planes of the NiO. The findings are consistent with the XRD data (Figure 2A). These results indicate the monocrystalline nature of the NiAl-LDH and NiAl-LDO. However, Figure 3E shows that, in $\mathrm{NiO} / \gamma-\mathrm{Al}_{2} \mathrm{O}_{3}$, a large amount of $\mathrm{NiO}$ aggregation on the surface of $\gamma-\mathrm{Al}_{2} \mathrm{O}_{3}$ during the processes of drying and calcination, which could block most of active sites and hinder the ion diffusion and charge transport. Further TEM of $\mathrm{NiO} / \gamma-\mathrm{Al}_{2} \mathrm{O}_{3}$ illustrates the existence of aggregated $\mathrm{NiO}$ in $\gamma-\mathrm{Al}_{2} \mathrm{O}_{3}$ (Figure $3 \mathrm{~F}$ ), in good agreement with the above SEM results. Furthermore, the EDS mapping of $\mathrm{NiO} / \gamma-\mathrm{Al}_{2} \mathrm{O}_{3}$ shows the heterogeneous distribution of $\mathrm{Ni}, \mathrm{Al}$ in $\gamma-\mathrm{Al}_{2} \mathrm{O}_{3}$ (Figure 3F). The above results sufficiently prove the $\mathrm{LDH}$-derived catalyst could maintain the layered structure and highly 
dispersed active species, which benefits the catalytic activity. Other LDH-derived catalysts have also been reported in other literature [36,37]. For instance, Li et al. [36] reported that the sulfureted $\mathrm{NiAl}-\mathrm{LDO}$ could maintain a layered structure even after $\mathrm{Na}_{2} \mathrm{~S}_{2} \mathrm{O}_{3}$ treatment and $400{ }^{\circ} \mathrm{C}$ calcination, exhibiting outstanding electrochemical activity.

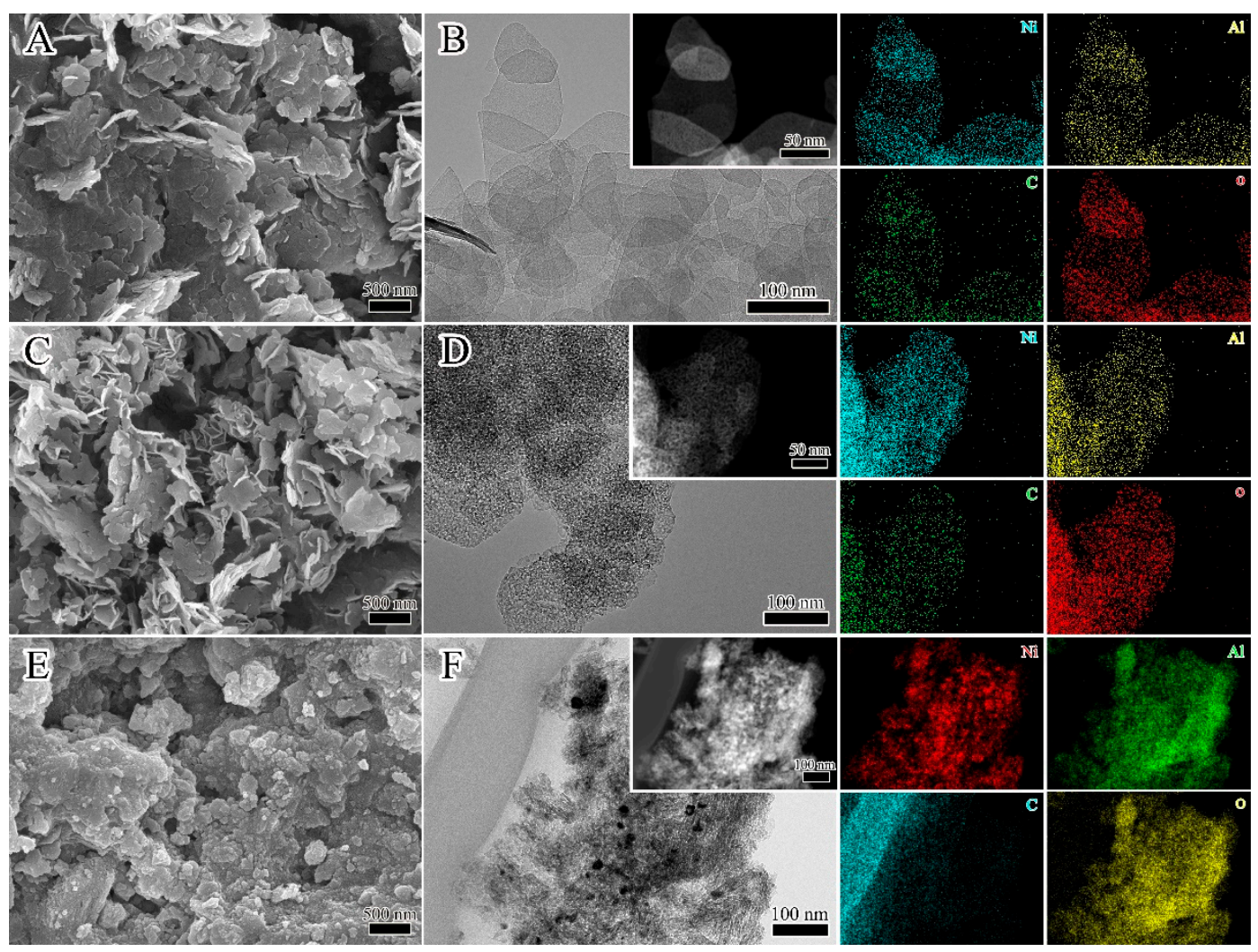

Figure 3. (A) SEM, (B) TEM and (inset in (B)) the corresponding EDS mapping pattern of NiAl-LDH; (C) SEM, (D) TEM and (inset in (D)) the corresponding EDS mapping pattern of NiAl-LDO; (E) SEM of $\mathrm{NiO} / \gamma-\mathrm{Al}_{2} \mathrm{O}_{3},(\mathbf{F})$ TEM and (inset in $(\mathbf{F})$ ) the corresponding EDS mapping pattern of $\mathrm{NiO} / \gamma-\mathrm{Al}_{2} \mathrm{O}_{3}$.

To further affirm the porous structure in NiAl-LDO, low temperature nitrogen adsorptiondesorption experiments were conducted. Comparing $\mathrm{NiO} / \gamma-\mathrm{Al}_{2} \mathrm{O}_{3}$ with $\mathrm{NiAl}-\mathrm{LDH}$, as shown in Figure $4 \mathrm{~A}, \mathrm{~B}$, the much wider micropores of NiAl-LDO confirm the porous structure, which corresponds well to the TEM result (Figure 3D). The average pore size decrease (from $12.65 \mathrm{~nm}$ of NiA-LDH to $8.12 \mathrm{~nm}$ of NiAl-LDO, Figure 4D) further proves the formation of pores with a lower size. Moreover, the specific surface area of the calcinated sample increases more than two times when compared with LDH precursors (64.34 $\mathrm{m}^{2} \mathrm{~g}^{-1}$ of NiAl-LDH and $185.63 \mathrm{~m}^{2} \mathrm{~g}^{-1}$ of NiAl-LDO, Figure 4D). Besides, the specific surface area of $\mathrm{NiO} / \gamma-\mathrm{Al}_{2} \mathrm{O}_{3}\left(173.43 \mathrm{~m}^{2} \mathrm{~g}^{-1}\right)$ obtained by impregnating and calcining methods is approached with that of pure $\gamma-\mathrm{Al}_{2} \mathrm{O}_{3}\left(179 \mathrm{~m}^{2} \mathrm{~g}^{-1}\right.$ [20]), but the dramatic declination of average pore size is discovered within it (18.1 nm [20] to $4.99 \mathrm{~nm})$. The blocking of micro-pore caused by impregnating nickel in $\gamma-\mathrm{Al}_{2} \mathrm{O}_{3}$ surface could suppress the catalytic exchange on $\mathrm{NiO} / \gamma-\mathrm{Al}_{2} \mathrm{O}_{3}$. 
A

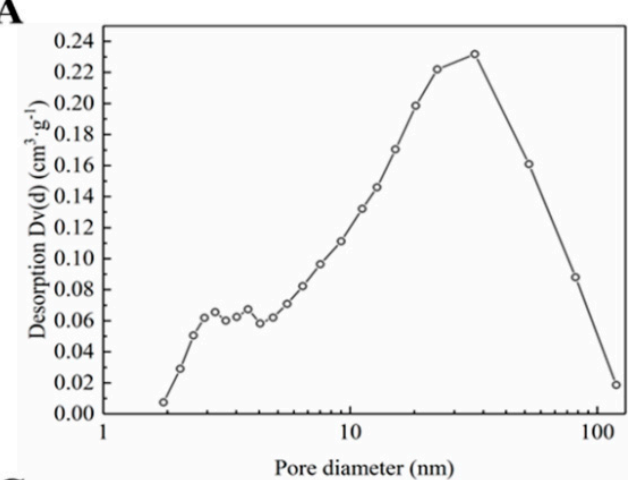

C

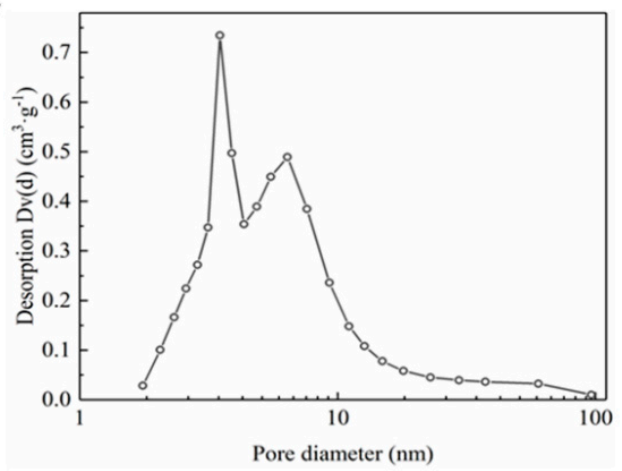

B

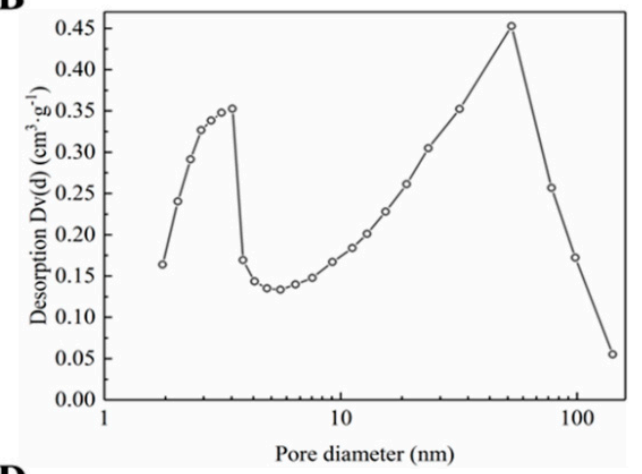

D

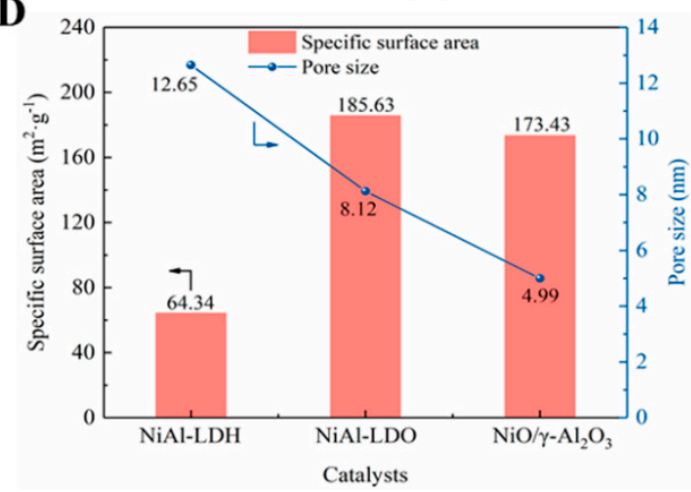

Figure 4. Curves of pore size distribution of (A) NiAl-LDH; (B) NiAl-LDO; (C) $\mathrm{NiO} / \gamma-\mathrm{Al}_{2} \mathrm{O}_{3}$ and (D) the corresponding textural parameters.

\subsection{Catalytic Performance on Hydrogen Isotope Exchange}

The VPCE catalytic performance evaluation apparatus was shown in Figure 1. As shown in Figure 5, the catalytic activity of the prepared NiAl-LDO is much higher than that of $\mathrm{NiO} / \gamma-\mathrm{Al}_{2} \mathrm{O}_{3}$ under the same test condition from $200{ }^{\circ} \mathrm{C}$ to $400{ }^{\circ} \mathrm{C}$, while $\mathrm{NiO} / \gamma-\mathrm{Al}_{2} \mathrm{O}_{3}$ exhibits similar catalytic performance with NiAl-LDO at $500{ }^{\circ} \mathrm{C}$. In industrial application, the VPCE process is preferred under a lower temperature with much fewer operating conditions and tritium permeation. Excitedly, catalytic activities of NiAl-LDO are more than nine times over that of impregnated $\mathrm{NiO} / \gamma-\mathrm{Al}_{2} \mathrm{O}_{3}$ at $300{ }^{\circ} \mathrm{C}$. Meanwhile, with the increment of temperature, the dedeuterium factor enhanced is obviously due to increased deuterium transfer from vapor to hydrogen. Besides, special structure characteristics (homogenous dispersion and flaky morphology, Figure 3C,D) of NiAl-LDO are available for the dynamic contact between gaseous water deuterium and hydrogen gas, leading to the higher catalytic activity of NiAl-LDO than $\mathrm{NiO} / \gamma-\mathrm{Al}_{2} \mathrm{O}_{3}$ under a temperature lower than $400{ }^{\circ} \mathrm{C}$.

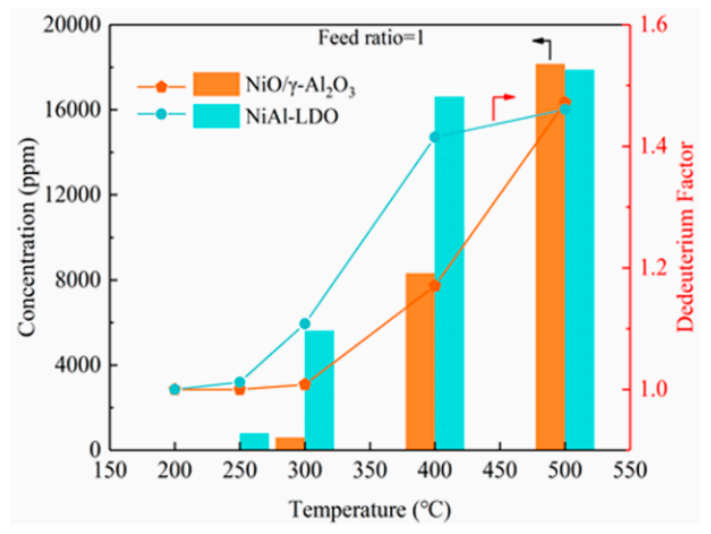

Figure 5. Catalytic performances of $\mathrm{NiAl}-\mathrm{LDO}$ and $\mathrm{NiO} / \gamma-\mathrm{Al}_{2} \mathrm{O}_{3}$, respectively. Molar feed ratio of hydrogen gas to feed water: $\lambda=1$. 
XPS was used to evaluate the surface chemical states of catalysts before and after reaction. As shown in Figure 6A, the XPS spectrum of $\mathrm{Al} 2 \mathrm{p}$ at $73.71 \mathrm{eV}$ is assigned to $\mathrm{Al}^{3+}$ and further proves the existence of $\mathrm{Al}_{2} \mathrm{O}_{3}$ crystallite in untested NiAl-LDO, which is in good agreement with the XRD results (Figure 2A). Meanwhile, the two spin-orbit doublets clearly locate at the binding energy of $855.8 \mathrm{eV}$ and $873.4 \mathrm{eV}$, respectively, which correspond to $\mathrm{Ni}^{2+} 2 \mathrm{p}_{3 / 2}$ and $\mathrm{Ni}^{2+} 2 \mathrm{p}_{1 / 2}$. The accompanying shake-up satellites are located at $861.8 \mathrm{eV}$ and $879.8 \mathrm{eV}$ on the side of the $\mathrm{Ni}^{2+} 2 \mathrm{p}_{3 / 2}$ and $2 \mathrm{p}_{1 / 2}$ edge, respectively, illustrating the presence of $\mathrm{Ni}^{2+}$ in un-tested $\mathrm{NiAl}-\mathrm{LDO}$, in good accordance with the literature [36,38]. Comparing tested NiAl-LDO with an untested one, the slight shift of Al binding energy also is detected from $73.71 \mathrm{eV}$ to $74.58 \mathrm{eV}$, which reveals stronger metal-support interactions

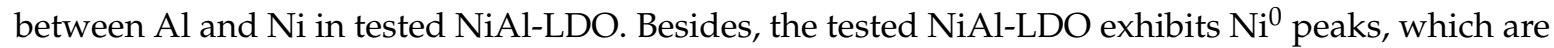
displayed as two weaker peaks at $852.4 \mathrm{eV}$ and $870.1 \mathrm{eV}$, respectively [21,39]. Moreover, two spin-orbit doublets (located at $854.7 \mathrm{eV}$ and $872.8 \mathrm{eV}$, respectively) and their shakeup satellites (shown at $859.6 \mathrm{eV}$ and $878.9 \mathrm{eV}$, respectively) shift to a lower binding energy, demonstrating that the interaction of the $\mathrm{Ni}-\mathrm{O}$ bond becomes weaker. Simultaneously, the relative intensity of the $\mathrm{Ni}^{2+}$ species decrease (from $100 \%$ of untested NiAl-LDO to $97.86 \%$ of the tested one, Table S2), illustrating that the content of $\mathrm{NiO}$ decreases after the VPCE process. Comparing tested $\mathrm{NiO} / \gamma-\mathrm{Al}_{2} \mathrm{O}_{3}$ with tested $\mathrm{NiAl}-\mathrm{LDO}$, as shown in Figure $6 \mathrm{C}, \mathrm{D}$, the XPS spectrum of $\mathrm{Al} 2 \mathrm{p}$ in tested $\mathrm{NiO} / \gamma-\mathrm{Al}_{2} \mathrm{O}_{3}$ shifts toward a lower binding energy (from $73.66 \mathrm{eV}$ to $73.60 \mathrm{eV}$ ). What is more, the two spin-orbit doublets (located at the binding energy of $872.83 \mathrm{eV}$ and $855.21 \mathrm{eV}$, respectively) shift toward a higher binding energy (873.30 eV and $856.10 \mathrm{eV}$, respectively) after the reaction. These results confirm weak metal-support interactions between $\mathrm{Al}$ and $\mathrm{Ni}$ in impregnated $\mathrm{NiO} / \gamma-\mathrm{Al}_{2} \mathrm{O}_{3}$. Meanwhile, the XPS spectrums of $\mathrm{Ni}^{0}$ in both tested catalysts were observed in Figure 6B,D, in good agreement with the corresponding XRD patterns (Figures S5 and S6). Above results reveals stronger metal-support interaction and both catalysts could be partially reduced under a test environment containing $\mathrm{H}_{2}$ and HDO. These two characters may be a benefit for higher catalytic activity, which would be discussed in the following section.
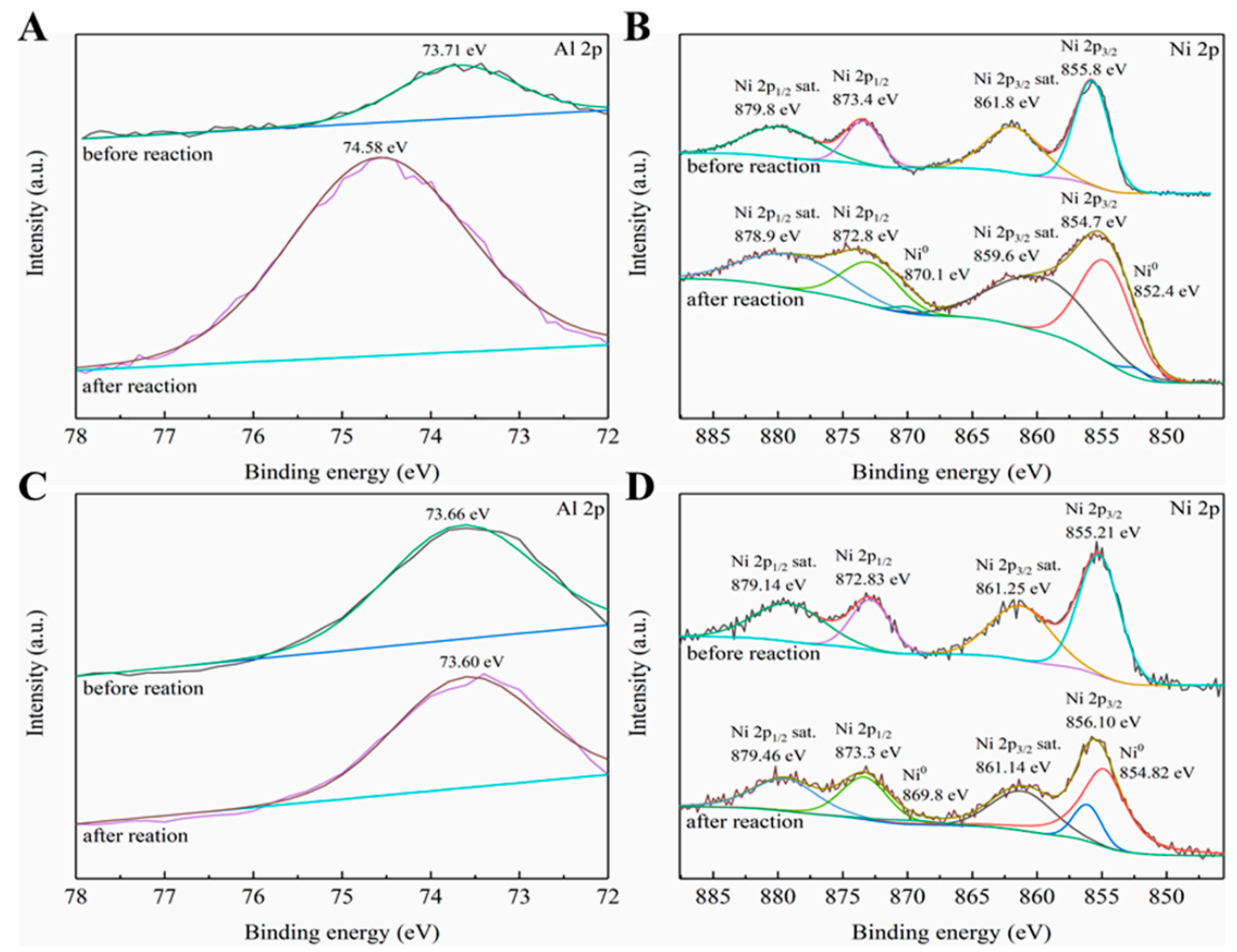

Figure 6. XPS of catalysts before and after reaction: (A,B) NiAl-LDO, (C,D) $\mathrm{NiO} / \gamma-\mathrm{Al}_{2} \mathrm{O}_{3}$ powders obtained by grinding a $\mathrm{NiO} / \gamma-\mathrm{Al}_{2} \mathrm{O}_{3}$ sphere. 


\subsection{Relationship between $\mathrm{Ni}^{0}$ Species and Catalytic Activity}

To further evaluate the influence of $\mathrm{Ni}^{0}$ species on catalytic activity, the catalytic performance of reduced NiAl-LDO (treated with different reduction temperatures under $\mathrm{H}_{2}$ atmosphere) were tested (Figure 7). After the reduction process, the catalytic activities of NiAl-LDO are obviously improved with the increase of reduction temperature below $300{ }^{\circ} \mathrm{C}$. When reaction temperature $>300{ }^{\circ} \mathrm{C}$, both catalysts (treated by a pre-reduction process at $500{ }^{\circ} \mathrm{C}$ and $700{ }^{\circ} \mathrm{C}$, respectively) exhibit similar catalytic activities. Differently, compared with the un-reduced samples (NiAl-LDO), catalytic performances are observed for the VPCE process and DF exhibits an obvious promotion under the reaction temperature range of $\sim 100-200^{\circ} \mathrm{C}$. The above experimental results demonstrate that the $\mathrm{Ni}^{0}$ species generated by an in-situ reduction of NiAl-LDO are able to promote catalytic activity below $300{ }^{\circ} \mathrm{C}$ for the VPCE reaction.

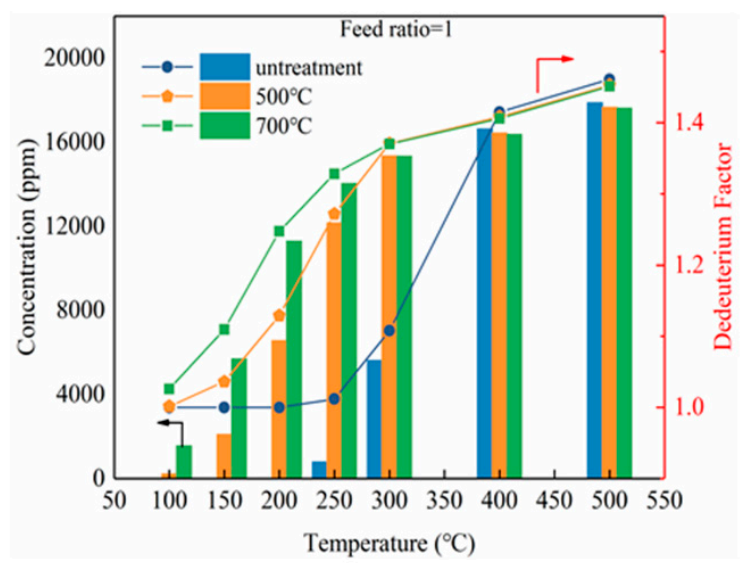

Figure 7. Catalytic performances of NiAl-LDO under different reduction temperatures. Molar feed ratio of hydrogen gas to feed water: $\lambda=1$. Reduction condition: $500{ }^{\circ} \mathrm{C}$ or $700{ }^{\circ} \mathrm{C}$ for $2 \mathrm{~h}$ with $\mathrm{H}_{2}(20$ $\mathrm{mL} \mathrm{min}^{-1}$, concentration: $\left.99.999 \%\right)$.

\subsection{Reduction Property for Catalysts}

To further characterize the reduction property and nature of metal-support interaction, the $\mathrm{H}_{2}-\mathrm{TPR}$ was conducted. As shown in Figure 8A, the TPR profiles of NiAl-LDH have a wide and strong peak centered around $598{ }^{\circ} \mathrm{C}$ and a shoulder peak at a lower temperature of $403{ }^{\circ} \mathrm{C}$. The main peak is assigned to the reduction of well distributed $\mathrm{Ni}^{2+}$ species in the metal oxide, while the shoulder peak is attributed to the reduction of $\mathrm{Ni}^{2+}$ in the form of the bulk crystallite $\mathrm{NiO}$ species [40]. Comparing NiAl-LDO with NiAl-LDH, as shown in Figure 8B, the single reduction peak of NiAl-LDO is discovered at around $603^{\circ} \mathrm{C}$, which corresponds to the reduction of $\mathrm{Ni}^{2+}$ to $\mathrm{Ni}^{0}$. The higher reduction temperatures (than pure $\mathrm{NiO}$ around $370^{\circ} \mathrm{C}$ [41]) of NiAl-LDH and NiAl-LDO could suggest stronger metal-support interactions between nickel and aluminum, which helps avoid nickel's agglomeration in special test condition with $\mathrm{H}_{2}$ and then promotes the catalytic activity. The results also demonstrate that $\mathrm{H}_{2}$ has a good accessibility to reduce nickel completely for NiAl-LDH and NiAl-LDO. Importantly, the absence of the reductive peak of NiAl-LDO at $<300{ }^{\circ} \mathrm{C}$ suggests that a reduction process cannot occur at below $30{ }^{\circ} \mathrm{C}$ and NiAl-LDO still maintains $\mathrm{NiO}$ components. Comparing the TPR profiles of $\mathrm{NiO} / \gamma-\mathrm{Al}_{2} \mathrm{O}_{3}$ and NiAl-LDO, lower reductive peak (centered at $308^{\circ} \mathrm{C}$ ) indicates weaker metal-support interactions between $\mathrm{Ni}$ and $\gamma-\mathrm{Al}_{2} \mathrm{O}_{3}$, leading to $\mathrm{NiO}$ aggregation on the surface of $\gamma-\mathrm{Al}_{2} \mathrm{O}_{3}$ supports and lower catalytic activity in the reaction process. The two reductive peaks (located at $308{ }^{\circ} \mathrm{C}$ and $565{ }^{\circ} \mathrm{C}$ ) are attributed to the reduction of $\mathrm{Ni}^{2+}$ interacting with near groups through the free $\mathrm{Ni}-\mathrm{O}$ bonds [42] or the reduction of highly dispersed $\mathrm{NiO}$ species [41]. Meanwhile, it can be obviously seen that NiAl-LDH and NiAl-LDO have similar actual $\mathrm{H}_{2}$ consumptions (7429 $\mu \mathrm{mol} \mathrm{g}^{-1}$ and $7086 \mu \mathrm{mol} \mathrm{g}^{-1}$, respectively) under the same loaded $\mathrm{Ni}$, showing the similar reduction property, which corresponds well to the similarly centered reduction temperature $\left(598^{\circ} \mathrm{C}\right.$ and $603^{\circ} \mathrm{C}$, respectively, Figure $\left.8 \mathrm{~A}, \mathrm{~B}\right)$. However, $\mathrm{NiO} / \gamma-\mathrm{Al}_{2} \mathrm{O}_{3}$ consumes smaller $\mathrm{H}_{2}$ due to a different synthetical method. The actual $\mathrm{H}_{2}$ consumption 
of NiAl-LDH is lower than the theoretical one $\left(9981 \mu \mathrm{mol} \mathrm{g}^{-1}\right)$ and $\mathrm{NiO} / \gamma-\mathrm{Al}_{2} \mathrm{O}_{3}$ catalysts show a similar phenomenon. On the other hand, catalytic activities of NiAl-LDO catalysts were observed at $250{ }^{\circ} \mathrm{C}$ in a reaction process while there is no reaction observed for $\mathrm{NiO} / \gamma-\mathrm{Al}_{2} \mathrm{O}_{3}$. One of the reasons is the better $\mathrm{Ni}$ dispersion helps to enhance the reaction, another is that $\mathrm{Ni}^{2+}$ could bring an availably active site and benefit to catalytic activities.

A

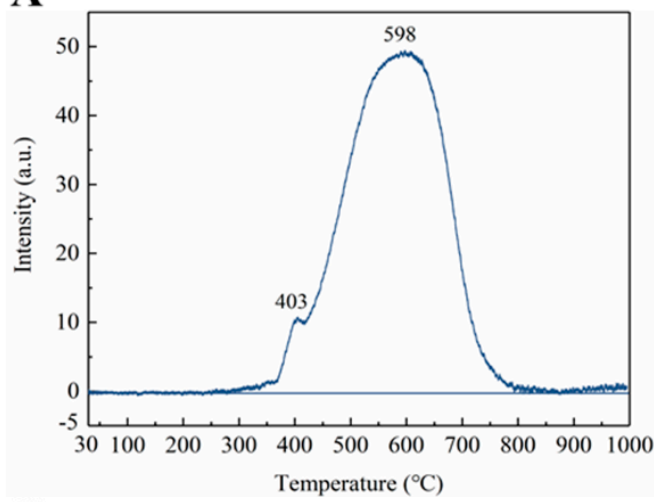

C

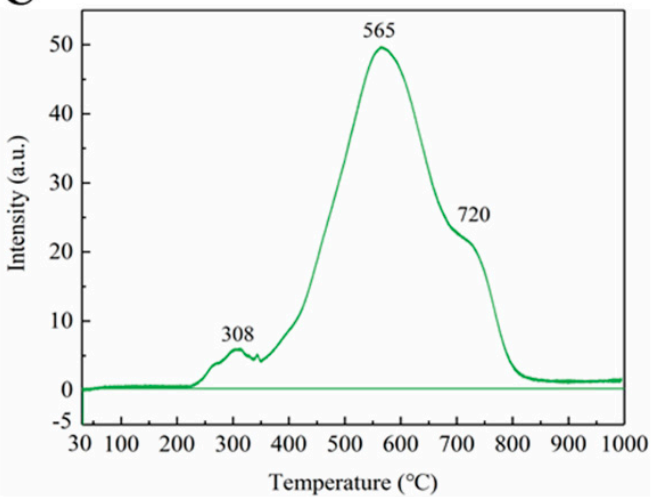

B

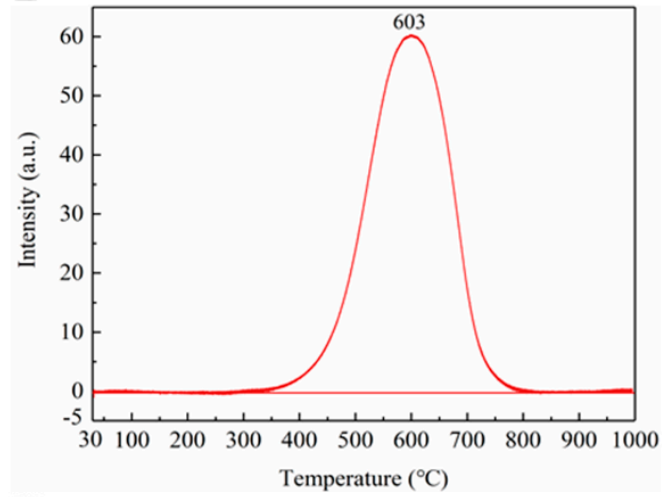

D

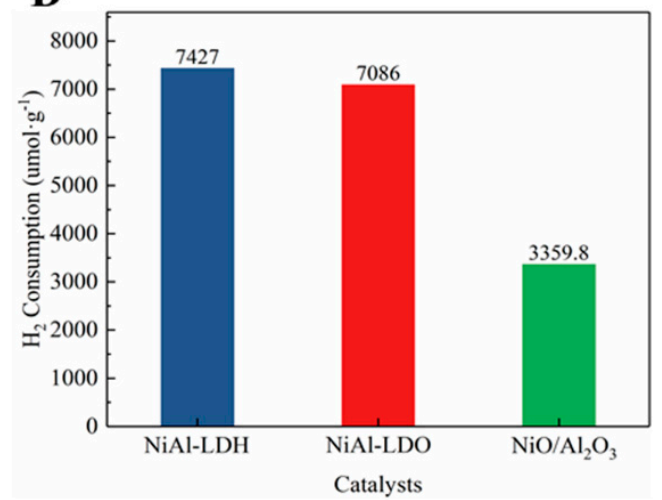

Figure 8. $\mathrm{H}_{2}$-TPR profiles of (A) NiAl-LDH, (B) NiAl-LDO, (C) $\mathrm{NiO} / \gamma-\mathrm{Al}_{2} \mathrm{O}_{3}$ and (D) the corresponding $\mathrm{H}_{2}$ consumptions.

The high temperature in the VPCE process prevents liquid water from blocking active sites of catalysts and therefore the whole transfer of deuterium occurs in a single stage, as shown in Equation (6):

$$
\mathrm{HDO}(\text { vapor })+\mathrm{H}_{2} \text { (gas) } \rightleftharpoons \mathrm{HD}(\text { gas })+\mathrm{H}_{2} \mathrm{O}(\text { gas }),
$$

As is well known, the catalytic reaction (Equation (6)) occurs on catalytic active sites. The catalytic reaction consists of the following steps: (1) enrichment of vaporous water and hydrogen; (2) diffusion and adsorption; (3) hydrogen isotope catalytic exchange; (4) desorption and diffusion. Based on the published research in science magazines, the pivotal mechanism is the dissociative chemisorption of $\mathrm{D}_{2} \mathrm{O}$ (or HDO) on $\mathrm{Ni}$ (111) crystal surface to form chemisorbed $\mathrm{OD}(\mathrm{ads}), \mathrm{D}$ (ads) or $\mathrm{OH}$ (ads), which has been confirmed by a quantum-dynamical investigation on a density functional theory (DFT) based global potential energy surface (PES) [43]. Meanwhile, hydrogen molecules can also dissociate into $\mathrm{H}(\mathrm{ads})$ on $\mathrm{Ni}$ (111) planes [44-46]. Therefore, it can be concluded that hydrogen and vaporous water are chemically adsorbed mainly on the $\mathrm{Ni}$ (111) planes and dissociate into a hydrogen atom, deuterium atom and hydrogen-deuterium atom. However, Figures 5 and $8 \mathrm{~B}$ show that catalytic activity exists at $250{ }^{\circ} \mathrm{C}$ and no reductive peak occurs at $<300^{\circ} \mathrm{C}$ for NiAl-LDO, suggesting that $\mathrm{Ni}^{2+}$ also bring catalytic performance in VPCE. In other words, another reaction pathway may coexist with the above-mentioned pathway. In the second pathway or route II, the dissociative chemisorption of $\mathrm{H}_{2}$ and $\mathrm{HDO}$ also occurs on the $\mathrm{NiO}$ species. Namely, there are two reaction pathways (route I and route II) for the VPCE 
on NiAl-LDO catalysts. Based on the above discussion, one possible pathway for the H-D isotopic exchange between hydrogen and water on metallic $\mathrm{Ni}$ and $\mathrm{NiO}$ can be deduced as follows:

$$
\begin{gathered}
\mathrm{H}_{2}+2 \sigma(\mathrm{M}) \rightleftharpoons \mathrm{H}(\text { ads })+\mathrm{H}(\text { ads }), \\
\mathrm{HDO}+2 \sigma(\mathrm{M}) \rightleftharpoons \mathrm{D}(\text { ads })+\mathrm{OH}(\text { ads }), \\
\mathrm{H}(\text { ads })+\mathrm{D}(\text { ads }) \rightleftharpoons \mathrm{HDads}+2 \sigma(\mathrm{M}), \\
\mathrm{H}(\text { ads })+\mathrm{OH}(\text { ads }) \rightleftharpoons \mathrm{H}_{2} \mathrm{O}+2 \sigma(\mathrm{M}),
\end{gathered}
$$

where $\sigma$ is the active site, while $\mathrm{M}$ represents $\mathrm{Ni}^{0}$ or $\mathrm{NiO}$.

\section{Conclusions}

The vapor phase exchange reaction (VPCE) is a crucial important reaction for water detritiation and tritium extraction from heavy water. The high dispersed Ni-based catalyst derived from LDH is proposed and verified with better catalytic performance than traditional impregnated Ni/ $\mathrm{Al}_{2} \mathrm{O}_{3}$ catalysts. Synthesis processes were systematically studied to optimize the preparation conditions and to improve the crystallinity of NiAl-LDH. As it was observed with the NiAl-LDH (synthesized at $150{ }^{\circ} \mathrm{C}$ for $12 \mathrm{~h}$ with $\mathrm{Ni} / \mathrm{Al} /$ urea molar ratio of 2/1/14), a marked crystallinity was found by the adopted urea hydrolysis method. Moreover, after the calcinated process, in-situ grown Ni-catalysts derived from NiAl-LDH were applied firstly in the VPCE process between hydrogen and water. Experiments showed that NiAl-LDO catalysts exhibit an excellent reaction performance several times higher than that of impregnated $\mathrm{NiO} / \gamma-\mathrm{Al}_{2} \mathrm{O}_{3}$ under a temperature of $<400{ }^{\circ} \mathrm{C}$, signifying a high potential large-scale application for VPCE. Then the better catalytic performance of NiAl-LDO was analyzed. Compared with impregnated $\mathrm{NiO} / \gamma-\mathrm{Al}_{2} \mathrm{O}_{3}$, a unique petal-like nanosheet structure made the Ni-based catalyst (NiAl-LDO) quicker at ion diffusion and charge transport. Stronger metal-support interactions between $\mathrm{Ni}$ and $\mathrm{Al}_{2} \mathrm{O}_{3}$ supports prevented active metals' aggregation. Furthermore, a homogenous dispersed metallic phase, higher specific surface area and wider pore with a smaller size provided more available active metals. These advantages led to a more excellent catalytic performance. Importantly, based on our discussions, we proposed the reaction pathways in the hydrogen isotope exchange between hydrogen and water. Both $\mathrm{Ni}^{0}$ species and $\mathrm{NiO}$ species showed catalytic activities in the VPCE process. This work highlights the application of an in-situ grown Ni-based catalyst derived from a NiAl-LDH precursor at a lower temperature in the VPCE process and the coexisting effects of $\mathrm{NiO}$ and $\mathrm{Ni}^{0}$ species on catalytic activities.

Supplementary Materials: The following are available online at http://www.mdpi.com/2079-4991/9/12/1688/s1, Figure S1: X-ray diffraction patterns of NiAl-LDH under different Ni/Al/urea molar ratios; Figure S2: X-ray diffraction patterns of NiAl-LDH under different crystallization times; Figure S3: X-ray diffraction patterns of NiAl-LDH under different crystallization temperatures; Figure S4: SAED patterns of samples; Figure S5: X-ray diffraction patterns of the tested NiAl-LDO; Figure S6: X-ray diffraction patterns of the tested $\mathrm{NiO} / \gamma-\mathrm{Al}_{2} \mathrm{O}_{3}$; Table S1: analysis of XRD patterns for NiAl-LDH prepared by adjusting hydrothermal time, hydrothermal temperature as well as Ni/Al/urea molar ratio; Table S2: properties of XPS spectra for catalysts before and after reaction.

Author Contributions: Conceptualization, P.L., J.S. and Y.L.; investigation and methodology, X.H., P.L.; study design, N.Z., J.L.; data collection and curation, Z.Z., C.L. and B.Y.; supervision, J.S. and Y.L.; writing-original draft, X.H.; writing—review \& editing, X.H., P.L. and X.Z.

Funding: This research was funded by the National Key Research and Development Program of China, Grant No. 2017YFE0300302, the Key Project of Applied \& Basic Research of Sichuan Province, Grant No. 18YYJC1594 and the Project of Institute of Materials, Grant No. TP03201705.

Conflicts of Interest: The authors declare no conflict of interest. 


\section{References}

1. Perevezentsev, A.N.; Bell, A.C.; Williams, J.; Brennan, P.D. Detritiation studies for JET decommissioning. Fusion Eng. Des. 2008, 83, 1364-1367. [CrossRef]

2. Zhou, J.B.; Liu, Y.; Wang, C. Dynamic equations of tritium concentration during wastewater (light water) containing tritium electrolysis. Int. J. Hydrogen Energy 2016, 41, 16014-16018. [CrossRef]

3. Bornea, A.; Petrutiu, C.; Zamfirache, M. Complex software dedicated for design and simulation of LPCE process for heavy water detritiation. Fusion Sci. Technol. 2015, 67, 270-273. [CrossRef]

4. Zhang, D.H.; Zhou, L.; Su, W.; Sun, Y. Equilibrium modeling for hydrogen isotope separation by cryogenic adsorption. Chin. J. Chem. Eng. 2006, 14, 526-531. [CrossRef]

5. Elnour, F. Reactivation of promoted nickel-catalysts for deuterium-exchange between hydrogen and water vapor-phase. Isotopes Environ. Health Stud. 1980, 16, 370-372. [CrossRef]

6. Abouelnour, F.H.; Belacy, A. Binary supported nickel catalysts for the deuterium exchange reaction between hydrogen and water vapour. Isotopes Environ. Health. Stud. 1980, 18, 131-132. [CrossRef]

7. Sagert, N.H.; Shawwood, P.E.; Pouteau, R.M.L. Hydrogen-Water Deuterium Exchange Over Metal Oxide Promoted Nickel Catalysts. Can. J. Chem. 1975, 53, 3257-3262. [CrossRef]

8. Kalyanam, K.M.; Sood, S.K. A Comparison of Process Characteristics for the Recovery of Tritium from Heavy Water and Light Water Systems. Fusion Sci. Technol. 2017, 14, 524-528. [CrossRef]

9. Ovcharov, A.V. More Precise Values of Separation Factors in Water-Hydrogen Isotopic Exchange for Modeling of Combined Electrolysis and Catalytic Exchange Process. Fusion Sci. Technol. 2017, 71, 333-338. [CrossRef]

10. Hu, S.; Hou, J.W.; Xiong, L.P.; Weng, K.P.; Ren, X.B.; Luo, Y.M. Preparation and characterization of hydrophobic Pt-Fe catalysts with enhanced catalytic activities for interface hydrogen isotope separation. J. Hazard. Mater. 2012, 209, 478-483. [CrossRef]

11. Hu, S.; Xiong, L.P.; Ren, X.B.; Wang, C.B.; Luo, Y.M. Pt-Ir binary hydrophobic catalysts: Effects of Ir content and particle size on catalytic performance for liquid phase catalytic exchange. Int. J. Hydrogen Energy 2009, 34, 8723-8732. [CrossRef]

12. Hui, C.L.; Li, X.G.; Hsing, I.M. Well-dispersed surfactant-stabilized Pt/C nanocatalysts for fuel cell application: Dispersion control and surfactant removal. Electrochim. Acta 2005, 51,711-719. [CrossRef]

13. Ye, L.S.; Luo, D.L.; Yang, W.; Guo, W.S.; Xu, Q.Y.; Jiang, C.L. Improved catalysts for hydrogen/deuterium exchange reactions. Int. J. Hydrogen Energy 2013, 38, 13596-13603. [CrossRef]

14. He, J.C.; Wang, H.Y.; Xiao, C.J.; Li, J.M.; Chen, P.; Hou, J.W. Preparation and performance of Pt/PTFE/Foam $\mathrm{SiC}$ as a hydrophobic catalyst for LPCE. Fusion Eng. Des. 2016, 113, 269-274. [CrossRef]

15. Ye, L.S.; Luo, D.L.; Yang, W.; Guo, W.S.; Xu, Q.Y.; Luo, L.Z. Preparation and characterization of hydrophobic carbon-supported Pt3M ( $\mathrm{M}=\mathrm{Fe}, \mathrm{Co}, \mathrm{Ni}$ and $\mathrm{Cr}$ ) bimetals for $\mathrm{H} / \mathrm{D}$ isotope separation between hydrogen and water. Int. J. Hydrogen Energy 2014, 39, 13793-13799. [CrossRef]

16. Davidson, R.B.; Vonhatten, P.; Schaub, M.; Ulrich, D. Commissioning and 1st operating experience at Darlington tritium removal facility. Fusion Technol. 2017, 14, 472-479. [CrossRef]

17. Pautrot, G.P. The tritium extraction facility at the institute-laue-langevin experience of operation with tritium. Fusion Sci. Technol. 2017, 14, 480-483. [CrossRef]

18. Sood, S.K.; Sissingh, R.A.P.; Kveton, O.K. Removal and Immobilization of Tritium from Ontario Hydro's Nuclear Generating Stations. Fusion Technol. 2017, 8, 2478-2485. [CrossRef]

19. Zhang, Z.M.; Tian, Y.; Zhang, L.J.; Hu, S.; Xiang, J.; Wang, Y.; Xu, L.L.; Liu, Q.; Zhang, S.; Hu, X. Impacts of nickel loading on properties, catalytic behaviors of $\mathrm{Ni} /$ gamma- $\mathrm{Al}_{2} \mathrm{O}_{3}$ catalysts and the reaction intermediates formed in methanation of $\mathrm{CO}_{2}$. Int. J. Hydrogen Energy 2019, 44, 9291-9306. [CrossRef]

20. Feng, J.T.; Lin, Y.J.; Evans, D.G.; Duan, X.; Li, D.Q. Enhanced metal dispersion and hydrodechlorination properties of a Ni/Al $\mathrm{Al}_{2}$ catalyst derived from layered double hydroxides. J. Catal. 2009, 266, 351-358. [CrossRef]

21. Guo, Z.L.; Zheng, J.E.; Liu, Y.; Chu, W. Insight into the role of metal/oxide interaction and Ni availabilities on NiAl mixed metal oxide catalysts for methane decomposition. Appl. Catal. A-GEN. 2018, 555, 1-11. [CrossRef]

22. David, G.E.; Robert, C.T.S. Structural Aspects of Layered Double Hydroxides. Structure and Bonding; Springer: Berlin/Heidelberg, Germany, 2005; pp. 1-87. 
23. Feng, J.T.; Ma, X.Y.; He, Y.F.; Evans, D.G.; Li, D.Q. Synthesis of hydrotalcite-supported shape-controlled Pd nanoparticles by a precipitation-reduction method. Appl. Catal. A-Gen. 2011, 413, 10-20. [CrossRef]

24. Zhang, X.; Zhao, Y.F.; Zhao, Y.X.; Shi, R.; Waterhouse, G.I.N.; Zhang, T.R. A Simple Synthetic Strategy toward Defect-Rich Porous Monolayer NiFe-Layered Double Hydroxide Nanosheets for Efficient Electrocatalytic Water Oxidation. Adv. Energy Mater. 2019, 9, 6. [CrossRef]

25. Zhao, L.; Li, X.Y.; Qu, Z.P.; Zhao, Q.D.; Liu, S.M.; Hu, X.J. The NiAl mixed oxides: The relation between basicity and $\mathrm{SO}_{2}$ removal capacity. Sep. Purif. Technol. 2011, 80, 345-350. [CrossRef]

26. Cavani, F.; Trifiro, F.; Vaccari, A. Hydrotalcite-type clays: Preparation, properties and applications. Catal. Today 1991, 11, 173-301. [CrossRef]

27. Li, J.; Chen, F.P.; Jin, G.P.; Feng, X.S.; Li, X.X. Removals of aqueous sulfur dioxide and hydrogen sulfide using $\mathrm{CeO}_{2}$-NiAl-LDHs coating activated carbon and its mix with carbon nano-tubes. Colloid Surf. A 2015, 476, 90-97. [CrossRef]

28. Zhu, Y.T.; Wang, D.L.; Yang, X.Y.; Liu, S.; Liu, D.; Liu, J.; Xiao, H.D.; Hao, X.T.; Liu, J.Q. Investigation of the dye-sensitized solar cell designed by a series of mixed metal oxides based on ZnAl-layered double hydroxide. Appl. Phys. A 2017, 123, 10. [CrossRef]

29. Li, P.L.; Guo, L.; Xiong, R.J.; Wen, M.; Yao, Y.; Zhang, Z.; Song, J.F.; Shi, Y.; Tang, T. Separation process study of liquid phase catalytic exchange reaction based on the Pt/C/PTFE catalysts. Chin. J. Chem. Eng. 2019, 27, 1837-1845. [CrossRef]

30. Kovanda, F.; Rojka, T.; Bezdicka, P.; Jiratova, K.; Obalova, L.; Pacultova, K.; Bastl, Z.; Grygar, T. Effect of hydrothermal treatment on properties of $\mathrm{Ni}$-Al layered double hydroxides and related mixed oxides. J. Solid State Chem. 2008, 182, 27-36. [CrossRef]

31. Chen, H.Y.; Zhang, F.Z.; Fu, S.S.; Duan, X. In situ microstructure control of oriented layered double hydroxide monolayer films with curved hexagonal crystals as superhydrophobic materials. Adv. Mater. 2006, 18, 23. [CrossRef]

32. Rudolf, C.; Dragoi, B.; Ungureanu, A.; Chirieac, A.; Royer, S.; Nastro, A.; Dumitriu, E. NiAl and CoAl materials derived from takovite-like LDHs and related structures as efficient chemoselective hydrogenation catalysts. Catal. Sci. Technol. 2014, 4, 179-189. [CrossRef]

33. Li, L.; Hui, K.S.; Hui, K.N.; Xia, Q.X.; Fu, J.J.; Cho, Y.R. Facile synthesis of NiAl layered double hydroxide nanoplates for high-performance asymmetric supercapacitor. J. Alloy Compd. 2017, 721, 803-812. [CrossRef]

34. Parida, K.M.; Pradhan, A.C.; Das, J.; Sahu, N. Synthesis and characterization of nano-sized porous gamma-alumina by control precipitation method. Mater. Chem. Phys. 2008, 113, 244-248. [CrossRef]

35. Wang, Z.C.; Fang, P.F.; Kumar, P.; Wang, W.W.; Liu, B.; Li, J. Controlled Growth of LDH Films with Enhanced Photocatalytic Activity in a Mixed Wastewater Treatment. Nanomaterials 2019, 9, 807. [CrossRef] [PubMed]

36. Li, L.; Hui, K.S.; Hui, K.N.; Cho, Y.R. Ultrathin petal-like NiAl layered double oxide/sulfide composites as an advanced electrode for high-performance asymmetric supercapacitors. J. Mater. Chem. A 2017, 5 , 19687-19696. [CrossRef]

37. Abdelsadek, Z.; Sehailia, M.; Halliche, D.; Gonzalez-Delacruz, V.M.; Holgado, J.P.; Bachari, K.; Caballero, A.; Cherifi, O. In-situ hydrogasification/regeneration of NiAl-hydrotalcite derived catalyst in the reaction of $\mathrm{CO}_{2}$ reforming of methane: A versatile approach to catalyst recycling. J. $\mathrm{CO}_{2}$ Util. 2016, 14, 98-105. [CrossRef]

38. Pang, H.; Wei, C.Z.; Li, X.X.; Li, G.C.; Ma, Y.H.; Li, S.J.; Chen, J.; Zhang, J.S. Microwave-assisted synthesis of $\mathrm{NiS}_{2}$ nanostructures for supercapacitors and cocatalytic enhancing photocatalytic $\mathrm{H}_{2}$ production. Sci. Rep. 2014. [CrossRef]

39. Yang, L.J.; Zhao, X.C.; Yang, R.Z.; Zhao, P.X.; Li, Y.T.; Yang, P.; Wang, J.C.; Astruc, D. In-situ growth of carbon nanotubes on $\mathrm{Ni} / \mathrm{NiO}$ nanofibers as efficient hydrogen evolution reaction catalysts in alkaline media. Appl. Surf. Sci. 2019, 491, 294-300. [CrossRef]

40. Del Arco, M.; Malet, P.; Trujillano, R.; Rives, V. Synthesis and characterization of hydrotalcites containing $\mathrm{Ni}(\mathrm{II})$ and $\mathrm{Fe}(\mathrm{III})$ and their calcination products. Chem. Mater. 1999, 11, 624-633. [CrossRef]

41. Cheng, D.D.; Wang, Z.L.; Xia, Y.Y.; Wang, Y.M.; Zhang, W.X.; Zhu, W.C. Catalytic amination of diethylene glycol with tertiarybutylamine over $\mathrm{Ni}-\mathrm{Al}_{2} \mathrm{O}_{3}$ catalysts with different $\mathrm{Ni} / \mathrm{Al}$ ratios. RSC Adv. 2016, 6, 102373-102380. [CrossRef]

42. Heracleous, E.; Lee, A.F.; Wilson, K.; Lemonidou, A.A. Investigation of Ni-based alumina-supported catalysts for the oxidative dehydrogenation of ethane to ethylene: Structural characterization and reactivity studies. J. Catal. 2005, 231, 159-171. [CrossRef] 
43. Hundt, P.M.; Jiang, B.; van Reijzen, M.E.; Guo, H.; Beck, R.D. Vibrationally Promoted Dissociation of Water on $\mathrm{Ni}(111)$. Science 2014, 355, 504-507. [CrossRef] [PubMed]

44. Hayward, D.O.; Taylor, A.O. On the translationally activated dissociative chemisorption of hydrogen and deuterium at a nickel (111) surface. Chem. Phys. Lett. 1988, 146, 221-226. [CrossRef]

45. Liu, H.Y.; Li, K.; Zhang, R.G.; Ling, L.X.; Wang, B.J. Insight into the influence of addition of a second metal Fe and supports with different morphology on $\mathrm{H}_{2}$ dissociation over $\mathrm{Ni} / \mathrm{MgO}$ catalysts. Appl. Surf. Sci. 2017, 426, 827-832. [CrossRef]

46. Yang, H.; Whitten, J.L. Dissociative adsorption of $\mathrm{H}_{2}$ on Ni (111). J. Chem. Phys. 1993, 98, 5039-5049. [CrossRef]

(C) 2019 by the authors. Licensee MDPI, Basel, Switzerland. This article is an open access article distributed under the terms and conditions of the Creative Commons Attribution (CC BY) license (http://creativecommons.org/licenses/by/4.0/). 